\title{
Estimates of virus- vs. grazing induced mortality of picophytoplankton in the North Sea during summer
}

\author{
A. C. Baudoux ${ }^{1,2}$, M. J. W. Veldhuis ${ }^{1}$, A. A. M. Noordeloos ${ }^{1}$, G. $\operatorname{van}$ Noort $^{1}$, \\ C. P. D. Brussaard ${ }^{1, *}$ \\ ${ }^{1}$ Department of Biological Oceanography, Royal Netherlands Institute for Sea Research, PO Box 59, 1790 AB Den Burg, \\ The Netherlands \\ ${ }^{2}$ Present address: Scripps Institution of Oceanography, University of California at San Diego, La Jolla, California 92093-0202, USA

\begin{abstract}
Microzooplankton grazing and virally mediated mortality of the eukaryotic (3 size classes) and prokaryotic (Synechococcus) picophytoplankton was investigated across the North Sea during summer 2003. The fate of picophytoplankton differed among algal groups and their area of occurrence. Highest viral lysis rates $\left(0.16\right.$ to $\left.0.23 \mathrm{~d}^{-1}\right)$ were recorded for specific picoeukaryotic groups in the coastal region and at a station at the deep chlorophyll a maximum (DCM). Viral lysis was insignificant at the other stations, despite a considerable percentage of dead algal cells (up to $38 \%$ ), as determined by staining with the live/dead dye SYTOX Green. Microzooplankton actively grazed on picoeukaryotes (average per group 0.2 to $0.4 \mathrm{~d}^{-1}$ ), independent of the region studied. Grazing on Synechococcus was restricted to the coastal waters $\left(0.7 \mathrm{~d}^{-1}\right)$. Grazing by microzooplankton consumed $40 \pm 27 \%$ (mean \pm SD) of the carbon produced by picophytoplankton, constituting in general the main loss factor. Viral lysis released $8 \pm 13 \%$ of the total picophytoplankton carbon production, and locally up to $32 \%$.
\end{abstract}

KEY WORDS: Viral lysis · Microzooplankton grazing · Phytoplankton mortality · Oligotrophic ecosystem $\cdot$ North Sea $\cdot$ Summer

Resale or republication not permitted without written consent of the publisher

\section{INTRODUCTION}

Marine phytoplankton is responsible for up to half of the total primary production on Earth, and hence plays a critical role in global carbon cycling (Geider et al. 2001). Traditionally, phytoplankton cells were treated as immortal unless they were preyed upon by zooplankton or lost by sedimentation through the water column. Over the past decade, our view of phytoplankton mortality has been transformed with the finding that algal cells can die by lysis. Reports of substantial algal cell lysis rates (Brussaard et al. 1995, 1996a, Agusti et al. 1998) and high fractions of dead phytoplankton cells (Veldhuis et al. 2001, Alonso-Laita \& Agusti 2006) in marine environments emphasized the significance of cell death for phytoplankton mortality. Algal cell death by lysis can be caused by different mechanisms, including viral infection (Suttle et al.
1990, Brussaard 2004a) and environmental stresses such as intense light (Berman-Frank et al. 2004), darkness (Berges \& Falkowski 1998), or nutrient depletion (Berman-Frank et al. 2004).

The partitioning of phytoplankton mortality into sinking, grazing, and cell lysis is important because these loss factors differentially affect the structure and the functioning of the pelagic microbial food web. Phytoplankton sedimentation results in the transfer of particulate organic matter from the pelagic towards the benthic ecosystems (Smetacek 1985), whilst grazing will mostly channel phytoplankton biomass to the higher trophic levels in the pelagic food web. Through cell lysis, phytoplankton biomass is converted to dissolved organic matter that becomes available for bacteria, hence forcing the food web towards a more regenerative pathway (Wilhelm \& Suttle 1999 and references therein). Knowledge of the relative contribu- 
tion of these loss factors for phytoplankton mortality is thus critical for an optimal understanding of the flow of energy and nutrients in marine environments.

Extensive field studies conducted in the North Sea indicated pronounced temporal variation in the ecological relevance of these different loss factors (Riegman et al. 1993, Brussaard et al. 1995, 1996a, Kuipers \& Witte 1999). During the eutrophic spring conditions in this temperate region, grazing by microzooplankton regulates the population of small-sized phytoplankton whereas larger counterparts escape grazing due to their size, and can form blooms (Riegman et al. 1993, Brussaard et al. 1996a). Sedimentation was reported to be responsible for the termination of the diatom bloom in early spring, whereas algal cell lysis accounted for up to $75 \%$ loss of the Phaeocystis globosa bloom (Brussaard et al. 1995). Recent investigations indicated that viruses were the primary cause of cell lysis (Brussaard et al. 2005a, Baudoux et al. 2006). The substantial consumption of nutrients during these spring bloom events forces the system towards a more oligotrophic status by summer. In summer, smaller-sized phytoplankton dominate the algal community (Kuipers \& Witte 1999). These algal cells are not likely to sink, due to their small (micrometer) size (Raven 1998), and grazing by microzooplankton is considered the major loss factor (Kuipers \& Witte 1999). However, virtually no data exist on the significance of virally mediated mortality for phytoplankton in the North Sea during summer (Brussaard et al. 1996b).

Our study compared the relative contributions of viral lysis and microzooplankton grazing of smallersized phytoplankton during oligotrophic summer conditions, and explored the variation in these loss factors across the North Sea.

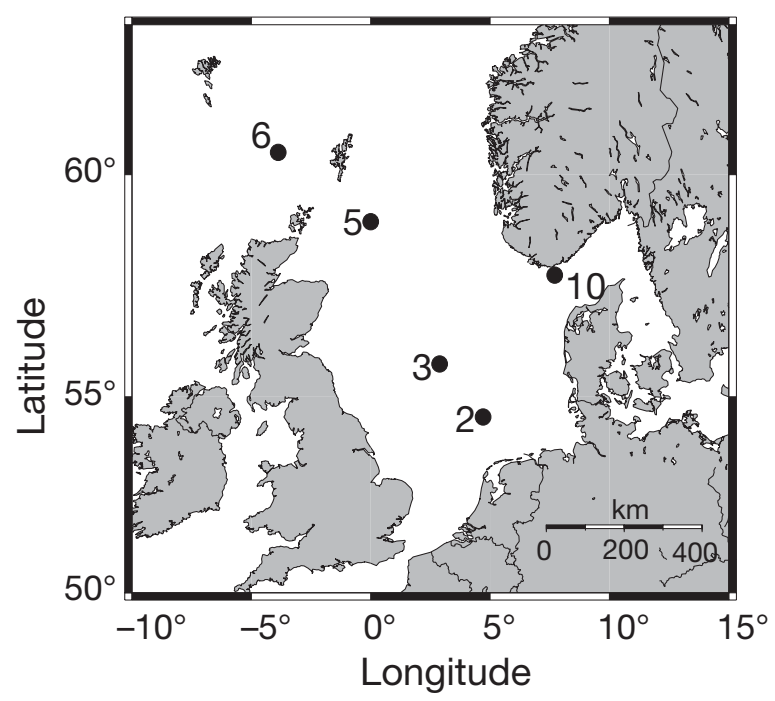

Fig. 1. Locations of the sampling stations

\section{MATERIALS AND METHODS}

Study area and sampling. The data were obtained during the MOMAP-2 shipboard expedition in the North Sea from 8 to 20 July 2003, aboard RV 'Pelagia' (Fig. 1). During this cruise, 5 pelagic stations were sampled for physical and chemical parameters, microbial abundance, phytoplankton viability (cell membrane integrity), microzooplankton grazing and viral lysis. Samples were collected in 101 NOEX bottles mounted on the Rosette sampler equipped with a Seabird conductivitytemperature-depth sensor (CTD). Sample collection was conducted at 6 different depths covering the upper $65 \mathrm{~m}$ of the water column except for Stn 2, where max. depth was $45 \mathrm{~m}$. The euphotic zone (1\% light penetration) comprised the upper 23 to $45 \mathrm{~m}$.

Physical and chemical parameters. The salinity, temperature and light intensities were measured by a CTD Seabird mounted on the Rosette sampler equipped with a photosynthetically active radiation (PAR) detector. The PAR detector was also mounted on deck to determine incident light. Nutrient samples $(5 \mathrm{ml})$ were filtered through $0.2 \mu \mathrm{m}$ polysulfone filters (Acrodisc, Gelman Sciences). Analyses were performed on board using a TrAAcs 800 autoanalyzer for dissolved orthophosphate, nitrate, nitrite, ammonium, and silicate as described in Baudoux et al. (2006). The limit of detection was $0.007 \mu \mathrm{M}$ for phosphate, $0.15 \mu \mathrm{M}$ for ammonium, $0.002 \mu \mathrm{M}$ for nitrite, $0.03 \mu \mathrm{M}$ for nitrate, and $0.02 \mu \mathrm{M}$ for silicate.

Phytoplankton community. Chl a samples (typically 1.5 l) were filtered onto a GF/F filter (Whatman) and stored at $-80^{\circ} \mathrm{C}$ until analysis. Chl a was extracted in $90 \%$ acetone and measured fluorometrically against a chl a standard originating from Anacystis nidulans (Sigma-Aldrich).

Phytoplankton abundance from natural as well as experimental samples was enumerated immediately after sampling using a Beckman Coulter XL-MCL flow cytometer. The instrument was equipped with a laser that had an excitation wavelength of $488 \mathrm{~nm}(15 \mathrm{~mW})$ and emission bands for chlorophyll autofluorescence (> $630 \mathrm{~nm}$ ) and phycoerythrin (PE; $575 \pm 20 \mathrm{~nm}$ ). The discriminator for phytoplankton was red chlorophyll autofluorescence. Flow rate $\left(135 \pm 7 \mu \mathrm{min}^{-1}\right)$ and machine drift were checked every day using calibrated beads (Flow-Check Fluorospheres, Beckman Coulter) as an internal standard. Based on pigment autofluorescence and forward scatter, we discriminated the prokaryotes Synechococcus spp. as well as 5 populations of eukaryotic cells (Fig. 2A). The division of the eukaryotes was based on their relative size, which was determined by flow cytometry using a series of fractionated samples $(10,8,5,3,2,1,0.6$, and $0.4 \mu \mathrm{m})$ as described by Veldhuis \& Kraay (2004). For each phyto- 
plankton cluster, the number of cells retained after each filtration step was measured and plotted as a function of filter pore-size. In a fitted S-shaped plot, the equivalent spherical diameter (ESD) was determined as the size displayed by the median ( $50 \%$ ) of the number of retained cells. This procedure was regularly
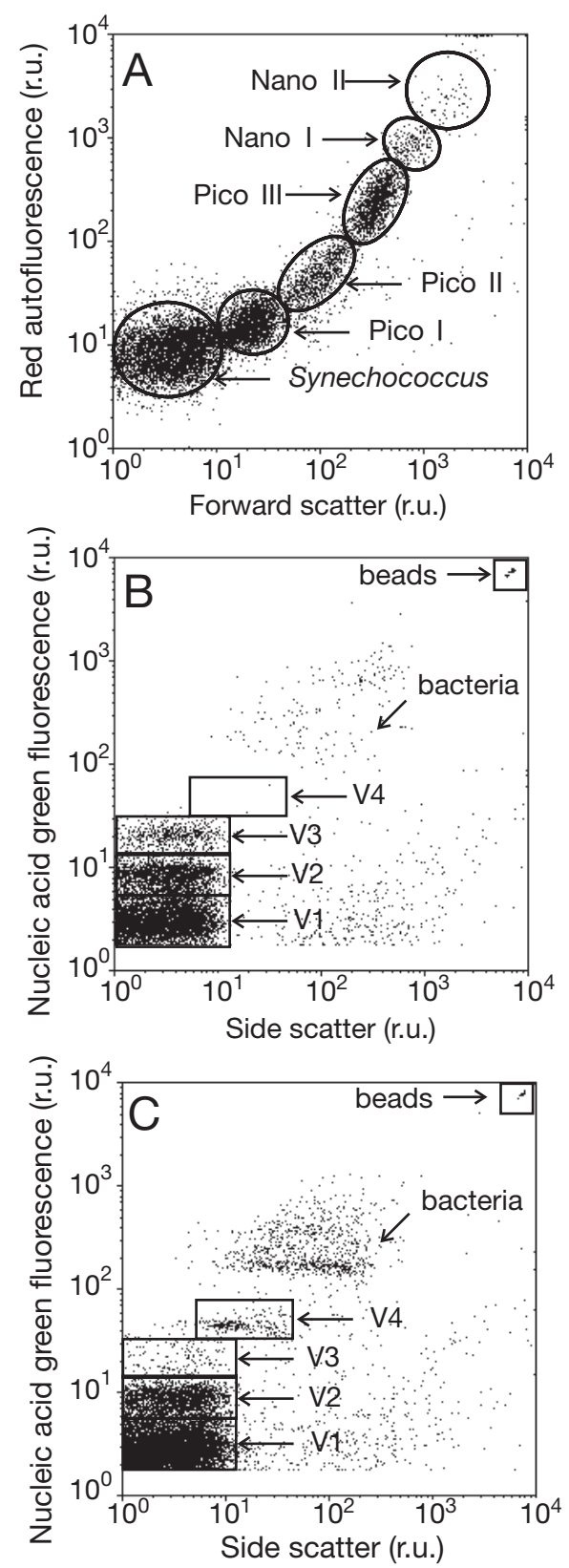

Fig. 2. (A) Cytogram of natural phytoplankton and typical virus community for (B) Stns 2, 3, 5 and 10 and (C) Stn 6. The phytoplankton community was dominated by the cyanobacteria Synechococcus, 3 picoeukaryotic populations and 2 nanoeukaryotic populations with lesser abundance. Four viral groups (V1, V2, V3, and V4) were identified. An internal standard (yellow green fluorescent $1 \mu \mathrm{m}$ beads, Invitrogen, Molecular Probes) was added to the sample; r.u.: relative units repeated during the cruise. The size parameter derived by flow cytometry (forward light scatter) showed a linear relationship with the ESD determined by the fractionated filtration procedure. This linear relationship was used to estimate the ESD of the different algal groups in each sample. Using this approach, the cyanobacterium Synechococcus had an ESD of $1.1 \mu \mathrm{m}$. Three picoeukaryotic groups were discriminated with ESD of 1.1-1.5 $\mu \mathrm{m}$ (Pico I), 1.5-2.0 $\mu \mathrm{m}$ (Pico II), and 2.0-3.0 $\mathrm{mm}$ (Pico III). Furthermore, we defined 2 nanoeukaryotic groups, in lesser abundance, with ESD of 3.0-6.0 $\mu \mathrm{m}$ (Nano I) and 10-20 $\mu \mathrm{m}$ (Nano II). The determination of the cellular carbon content of each phytoplankton group was based on biovolume, assuming that phytoplankton cells are spherical. For Synechococcus, we used an averaged biovolume to carbon

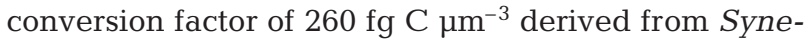
chococcus WH8103 and WH8012 (average diameter $1.02 \mu \mathrm{m}_{i}$ Bertilsson et al. 2003). For the picoeukaryotes, we used a biovolume to carbon conversion factor of $239 \mathrm{fg}^{-3}$, an average of the values obtained for

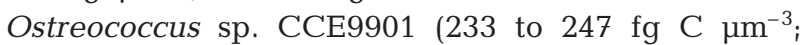
Worden et al. 2004) and Micromonas pusilla CCMP 489 (238 $\mathrm{fg}^{-3} \mathrm{~m}^{-3}$; DuRand et al. 2002). A biovolume to conversion factor of $160{\mathrm{fg} \mathrm{m}^{-3}}^{-3}$ was used for the nanoeukaryotes according to Verity et al. (1992). The resulting mean $( \pm \mathrm{SD})$ cellular carbon content was $0.18 \pm 0.004 \mathrm{pg} \mathrm{cell}^{-1}$ for Synechococcus, $0.22 \pm 0.02 \mathrm{pg}$ $\mathrm{cell}^{-1}$ for Pico I, $0.52 \pm 0.24 \mathrm{pg} \mathrm{cell}^{-1}$ for Pico II, $2.3 \pm$ $1.1 \mathrm{pg} \mathrm{cell}{ }^{-1}$ for Pico III, $8.0 \pm 5.4 \mathrm{pg} \mathrm{cell}^{-1}$ for Nano I and $321 \pm 707 \mathrm{pg} \mathrm{cell}^{-1}$ for Nano II.

The abundance of dead algal cells was determined using the nucleic acid-specific stain SYTOX Green (Molecular Probes, Invitrogen) to test cell membrane permeability (Veldhuis et al. 2001). SYTOX Green can only penetrate and stain cells with a compromised plasma membrane (i.e. dying cells). Briefly, samples were stained with SYTOX Green (final concentration $0.5 \mu \mathrm{M}$ ) for $15 \mathrm{~min}$ in the dark prior to flow cytometric analysis using a Beckman Coulter XL-MCL flow cytometer (see above section for instrument specification). Within each phytoplankton subgroup, cells were distinguished as alive or dead on the basis of their relative green fluorescence. Cells were defined as dead if the green fluorescence of SYTOX Green stained cells exceeded the green autofluorescence of unstained cells by at least 5-fold (see Brussaard et al. 2001, Veldhuis et al. 2001). Only the numerically dominant picophytoplankton groups (Synechococcus, and Pico I, II, and III) allowed proper analysis (typically down to a depth of $45 \mathrm{~m}$ ).

Virus community. The virus abundance was determined on glutaraldehyde-fixed samples (final concentration $0.5 \%$ glutaraldehyde, frozen in liquid nitrogen and stored at $-80^{\circ} \mathrm{C}$ prior to analysis) accord- 
ing to Brussaard (2004b), using a Beckton-Dickinson FACSCalibur flow cytometer equipped with a $15 \mathrm{~mW}$ $488 \mathrm{~nm}$ air-cooled argon-ion laser and a standard filter set up. The discriminator for virus enumeration was the green fluorescence. Thawed samples were 100-fold diluted in $0.2 \mu \mathrm{m}$ filtered autoclaved TE-buffer ( $\mathrm{pH}$ 8) and stained with SYBR Green I $\left(0.5 \times 10^{-4}\right.$ of the commercial stock) for $10 \mathrm{~min}$ at $80^{\circ} \mathrm{C}$ in darkness. Counts were corrected for the blanks consisting of TE-buffer with sterile $0.2 \mu \mathrm{m}$ filtered seawater in the correct dilution and treated identically to the samples. Based on their relative green fluorescence and side scatter signature we distinguished 4 virus subpopulations (V1, V2, V3, and V4; Fig. 2B,C).

Viral diversity was examined in the surface waters ( $5 \mathrm{~m}$ ) for all stations and at the DCM of Stns 2 and 3 using pulsed field gel electrophoresis (PFGE) as described by Larsen et al. (2001). A 21 water sample was concentrated using a VivaFlow 200 ultrafiltration system (30000 MWCO, PES, Vivascience) and was clarified of bacteria and cell debris by low speed centrifugation $\left(7500 \times g, 30 \mathrm{~min}\right.$ at $4^{\circ} \mathrm{C}$ with fixed angle rotor F-34-6-38 and using a 5810R centrifuge, Eppendorf). These samples were stored at $-80^{\circ} \mathrm{C}$ and analyzed within 6 mo. Thawed samples were further concentrated by ultracentrifugation $\left(141000 \times g, 2 \mathrm{~h}\right.$ at $8^{\circ} \mathrm{C}$, with a rotor TFF55.38 and using a CentrikonT-1080 ultracentrifuge, Kontron Instruments). Viral pellets were resuspended overnight in $150 \mu$ l of SM buffer $\left(0.1 \mathrm{M} \mathrm{NaCl}, 8 \mathrm{mM} \mathrm{MgSO} \mathrm{M}_{4} \cdot 7 \mathrm{H}_{2} \mathrm{O}, 50 \mathrm{mM}\right.$ Tris- $\mathrm{HCl}$, $0.0005 \%$ (w/v) glycerin; Wommack et al. 1999). The virus concentrates were plugged in molten InCert agarose $(1.5 \% \quad(\mathrm{w} / \mathrm{v})$, Cambrex Bioscience) and digested overnight at $30^{\circ} \mathrm{C}$ in a lysis buffer $(50 \mathrm{mM}$ EDTA, $1 \%$ SDS (v/v), $1 \mathrm{mg} \mathrm{ml}^{-1}$ Proteinase K). Samples were loaded onto a $1 \%$ SeaKem GTG agarose gel (Cambrex Bioscience); PFGE was performed using a Bio-Rad DR-II CHEF Cell unit operating at $6 \mathrm{~V} \mathrm{~cm}^{-1}$ at $14^{\circ} \mathrm{C}$ in $0.5 \times \mathrm{TBE}$ tank buffer. Two pulse ramp settings were used for optimal sizing of viral genomes: (1) 1 to $6 \mathrm{~s}$ for $20 \mathrm{~h}$ to examine the smaller virus genomes ranging from 10 to $100 \mathrm{~kb}$ and (2) 8 to $30 \mathrm{~s}$ for $20 \mathrm{~h}$ to dis- criminate the larger virus genomes ranging from 50 to $400 \mathrm{~kb}$. After electrophoresis, gels were stained for $1 \mathrm{~h}$ with SYBR Green I $\left(1 \times 10^{-4}\right.$ of commercial solution) and destained for $10 \mathrm{~min}$ in Milli-Q before a digital analysis for fluorescence using a FluorS imager (BioRad Laboratories). Viral genomes sizing was performed against a $5 \mathrm{~kb}$ lambda ladder or a lambda concatamers ladder (Bio-Rad Laboratories). A DNA quantification of each observed band was performed using the DNA standard Hyperladder VI (Gentaur). This analysis allowed us to determine the number of viral genome copies within a given band as described by Steward (2001).

Phytoplankton mortality assays. Phytoplankton viral lysis and microzooplankton $(<200 \mu \mathrm{m}$, mainly protozooplankton) grazing rates were determined in surface waters $(5 \mathrm{~m})$ at all stations (Table 1). An additional experiment was also performed at the deep chl a maximum depth (DCM, $37 \mathrm{~m}$ ) for Stn 3 (Table 1). Sample collection was performed by carefully siphoning from NOEX bottles into darkened carboys to prevent light stress when the sample was brought on deck. All materials used for these experiments were acid cleaned $(0.1 \mathrm{~N} \mathrm{HCl})$, and rinsed with Milli-Q and with the same water as the sample. The experimental set up was performed in a controlled room at in situ temperature (10 to $19^{\circ} \mathrm{C}$ ) and in dimmed light.

We estimated viral lysis and microzooplankton grazing rates using a modified dilution technique (Evans et al. 2003), with adaptations according to Baudoux et al. (2006). The data analysis was restricted to the numerically dominant picophytoplankton groups (Synechococcus, Pico I, II, and III), as algal abundance needs to be high enough to allow detection after a 5-fold dilution. Briefly, the natural sample $(<200 \mu \mathrm{m})$ was diluted in $0.2 \mu \mathrm{m}$ filtered seawater at 4 levels $(20,40,70$, and $100 \%$ of whole water) to obtain the microzooplankton grazing rate (Landry \& Hassett 1982). An additional dilution series in $30 \mathrm{kDa}$ filtered natural sample was performed to determine the loss rates resulting from grazing and viral lysis. To prevent losses of virus and grazers or cell disruption, the sample was handled with

Table 1. Location and characteristics of the 5 main stations investigated during this study. Note that Stn 3 was sampled both at surface $(5 \mathrm{~m})$ and at DCM $(37 \mathrm{~m})$ depths

\begin{tabular}{|c|c|c|c|c|c|c|c|c|c|c|c|}
\hline Stn & $\begin{array}{l}\text { Latitude } \\
\qquad\left({ }^{\circ} \mathrm{N}\right)\end{array}$ & $\begin{array}{l}\text { Longitude } \\
\left({ }^{\circ} \mathrm{W}\right)\end{array}$ & $\begin{array}{l}\text { Depth } \\
\text { (m) }\end{array}$ & $\begin{array}{c}\text { Temp. } \\
\left({ }^{\circ} \mathrm{C}\right)\end{array}$ & Salinity & $\begin{array}{l}\mathrm{NO}_{3} \\
(\mu \mathrm{M})\end{array}$ & $\begin{array}{l}\mathrm{NO}_{2} \\
(\mu \mathrm{M})\end{array}$ & $\begin{array}{l}\mathrm{NH}_{4} \\
(\mu \mathrm{M})\end{array}$ & $\begin{array}{l}\mathrm{PO}_{4} \\
(\mu \mathrm{M})\end{array}$ & $\begin{array}{c}\mathrm{Si} \\
(\mu \mathrm{M})\end{array}$ & $\begin{array}{c}\text { Chl a } \\
\left(\mu g l^{-1}\right)\end{array}$ \\
\hline 2 & 54.52 & 4.70 & 5 & 16.0 & 34.2 & 0.03 & 0.01 & 0.16 & 0.02 & 0.04 & 0.51 \\
\hline 3 & 55.83 & 2.67 & 5 & 15.5 & 35.0 & 0.06 & 0.01 & 0.12 & 0.03 & 0.81 & 0.25 \\
\hline 3 & 55.83 & 2.67 & 37 & 9.9 & 35.0 & 0.35 & 0.06 & 0.60 & 0.24 & 2.9 & 0.83 \\
\hline 5 & 59.01 & -0.02 & 5 & 14.4 & 35.2 & 0.24 & 0.01 & 0.27 & 0.03 & 0.21 & 0.28 \\
\hline 6 & 60.48 & -3.89 & 5 & 12.8 & 35.3 & 2.33 & 0.11 & 0.19 & 0.11 & 0.34 & 1.77 \\
\hline 10 & 57.83 & 7.70 & 5 & 19.2 & 31.7 & 0.06 & 0.01 & 0.12 & 0.01 & 0.27 & 0.68 \\
\hline
\end{tabular}


special care; transfers of sample were exclusively performed by siphoning and avoiding air bubbling. Sieving (50 $\mu \mathrm{m}$ mesh) and prefiltration ( $3 \mu \mathrm{m}$ pore size) steps were performed prior to the $0.2 \mu \mathrm{m}$ filtration. Polycarbonate Poretics filters (142 mm diameter, Millipore) were exclusively used and were replaced frequently during filtration to avoid loss of viral infectivity and abundance (Suttle et al. 1991). Test experiments showed that $93 \%$ of the virus community was retrieved after $0.2 \mu \mathrm{m}$ filtration. A detailed experimental design of the modified dilution method can be found in Baudoux et al. (2006).

A $5 \mathrm{ml}$ subsample was taken at time $0(\mathrm{~T}=0)$ from the soft polycarbonate incubation bottles (triplicate) upon filling, after which the bottles were closed without trapping air bubbles inside. All bottles were mounted on a slowly rotating $(0.5 \mathrm{rpm})$ plankton wheel. Incubation temperature $\left(10\right.$ to $\left.19^{\circ} \mathrm{C}\right)$ and irradiance (3 to $120 \mu \mathrm{mol}$ quanta $\mathrm{m}^{-2} \mathrm{~s}^{-1}$, light period of $14 \mathrm{~h}$ ) were adjusted to the in situ conditions given by the CTD and PAR detectors. After $24 \mathrm{~h}$ incubation, another $5 \mathrm{ml}$ subsample was taken to monitor phytoplankton growth using flow cytometry. The apparent growth rate $\left(\mu_{\mathrm{app}}, \mathrm{d}^{-1}\right)$ was calculated for each sample from the change in abundance during the incubation. The regression coefficient of apparent growth rate vs. dilution factor for the $30 \mathrm{kDa}$ series represents phytoplankton losses due to microzooplankton grazing and viral lysis $\left(M_{\mathrm{g}+\mathrm{v}}, \mathrm{d}^{-1}\right)$, whereas the regression coefficient resulting from the $0.2 \mu \mathrm{m}$ dilution series represents only the microzooplankton grazing rate $\left(M_{\mathrm{g}}\right.$, $\left.\mathrm{d}^{-1}\right)$. Specific virally induced mortality rates $\left(\mathrm{d}^{-1}\right)$ were thus obtained from the difference between $M_{\mathrm{g}+\mathrm{v}}$ and $M_{\mathrm{g}}$. Specific growth rates $\left(\mu, \mathrm{d}^{-1}\right)$ were determined as the $y$-intercept value of the regression line obtained with the $30 \mathrm{kDa}$ series. The significance (p) of each slope $\left(M_{\mathrm{g}}\right.$ and $\left.M_{\mathrm{g}+\mathrm{v}}\right)$ and the intercept $(\mu)$ were determined with a $t$-test on the regression analysis. The significance (p) of the difference between the slopes of the regressions lines (i.e. significance of $M_{\mathrm{v}}$ ) was also estimated using a $t$-test. In case we failed to detect significant differences between $M_{\mathrm{g}}$ and $M_{\mathrm{g}+\mathrm{v}}$, the sensitivity of the modified dilution technique was assessed using Power Analysis (Bayne et al. 1981, Kimmance et al. 2007).

In parallel, the protistan grazing rates on cyanobacteria were also determined using the fluorescently labeled prey approach. Labeling of Synechococcus sp. S1 ( $1 \mu$ m diameter, NIOZ culture collection) was performed prior to the cruise with 4,6-dichlorotriazin-2-yl aminofluorescein (DTAF, Sigma-Aldrich) according to Sherr \& Sherr (1993). The fluorescently labeled cyanobacteria (FLC) were enumerated by epifluorescence microscopy (Zeiss, Axioplan $12500 \mathrm{X}$ ), and aliquots of known concentration were stored at $-20^{\circ} \mathrm{C}$ until use. On board, FLC were diluted to $<10 \%(\mathrm{v} / \mathrm{v})$ of the natural cyanobacterial abundance by adding natural samples (triplicate, 11 polycarbonate bottles). A $20 \mathrm{ml}$ subsample ( $\mathrm{T}=0$ ) was taken upon filling and immediately fixed with $10 \%$ glutaraldehyde (1\% final concentration). The fixed sample was filtered onto a $0.2 \mu \mathrm{m}$ pore-size black membrane polycarbonate filter (Whatman) and stored at $-20^{\circ} \mathrm{C}$ until analysis. Bottles were closed and incubated as described for the modified dilution assay. After $24 \mathrm{~h}$ incubation, another $20 \mathrm{ml}$ subsample was taken and treated similarly for monitoring the abundance of FLC. The estimation of the grazing rates $\left(\mathrm{d}^{-1}\right)$ of Synechococcus was based on the decrease in abundance of FLC. Controls of FLC in $0.2 \mu \mathrm{m}$ filtered seawater showed no significant spontaneous decay of FLCs during the incubation time.

A carbon budget was determined by combining the cellular carbon content estimates (see phytoplankton community section) and data from the dilution experiments. For each specific phytoplankton group, the carbon production ( $C P$ in $\mu \mathrm{g} \mathrm{C}^{-1} \mathrm{~d}^{-1}$ ), losses due to grazing $\left(G, \mu \mathrm{C}^{-1} \mathrm{~d}^{-1}\right)$ and, by adaptation, losses due to viruses ( $V$, in $\mu \mathrm{g} \mathrm{C}^{-1} \mathrm{~d}^{-1}$ ) were calculated using the formulas of Landry et al. (2000); $C P=\mu \times P_{\mathrm{m} i} G=M_{\mathrm{g}} \times$ $P_{\mathrm{m} i} V=M_{\mathrm{v}} \times P_{\mathrm{m} i}$ and $P_{\mathrm{m}}=P_{0} \times\left[\mathrm{e}^{\left(\mu-M_{\mathrm{g}+\mathrm{v}}\right) t}-1\right] /(\mu-$ $\left.M_{\mathrm{g}+\mathrm{v}}\right) t$, where $\mu$ (in $\mathrm{d}^{-1}$ ) is the dilution-based specific growth ( $y$-intercept of the $30 \mathrm{kDa}$ regression); $M_{\mathrm{g}}$ and $M_{\mathrm{v}}$ are the dilution-based grazing and viral lysis rates (in $\mathrm{d}^{-1}$ ), $P_{0}$ (in $\mu \mathrm{g} \mathrm{C}^{-1}$ ) is the initial carbon biomass of

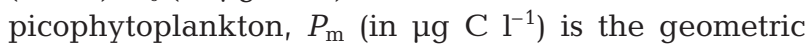
mean carbon biomass of picophytoplankton during the incubation, and $t$ (in $\mathrm{d}$ ) is the time of incubation.

\section{RESULTS}

\section{Physical and chemical characterization of the studied area}

The T-S diagrams for the entire water columns of the 5 stations differed significantly (Fig. 3). Stn 2 showed intermediate and constant salinity (34.2) and temperatures ranging between 11.1 and $16^{\circ} \mathrm{C}$ across depths. The stations sampled in the central and northern regions of the North Sea (Stns 3, 5, and 6) had the most saline waters (34.9 to 35.5$)$. However, the temperature range of these stations varied considerably within this latter region. Stns 3 and 5 had a broader temperature range $\left(7.3\right.$ to $15.5^{\circ} \mathrm{C}$ ) than Stn 6 (temperature range of 9.4 to $12.7^{\circ} \mathrm{C}$ ). Stn 10 was characterized by the largest gradients in salinity (29 to 34.7 ) and temperature (6.3 to $19.5^{\circ} \mathrm{C}$ ). Thermal stratification was observed at Stns 2, 3,5 , and 10 but not at Stn 6 . Among the 4 stratified stations, only Stns 2, 3 and 5 presented a well defined surface mixed layer extending to about $15 \mathrm{~m}$. 


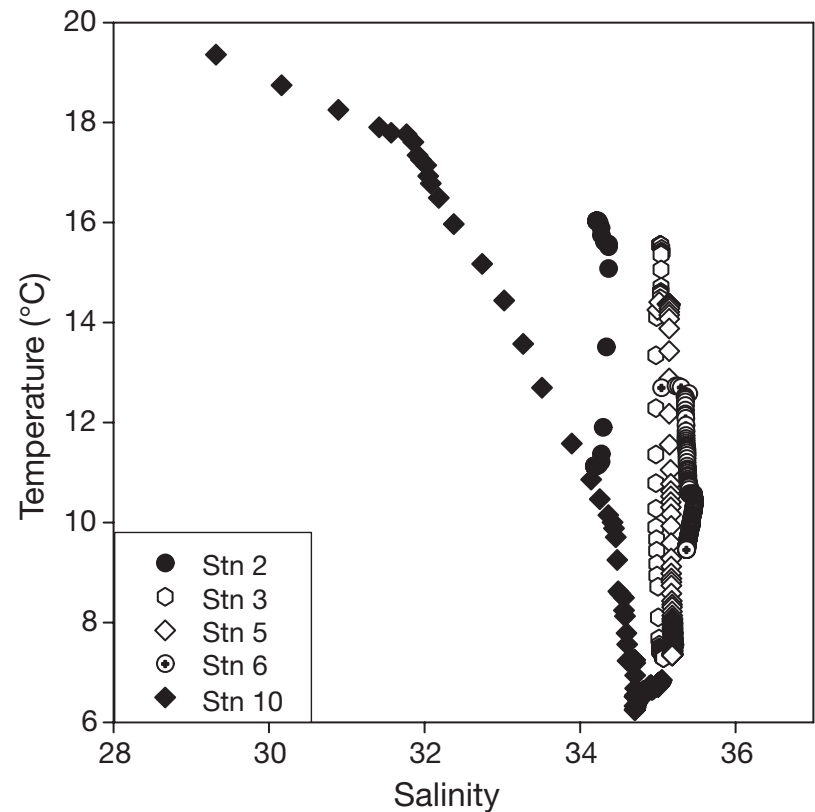

Fig. 3. Temperature-salinity (T-S) diagrams for the 5 stations, from the surface (top) to 43 to $247 \mathrm{~m}$ depth (bottom)

The surface water (down to $20 \mathrm{~m}$ ) concentrations of inorganic nutrients were $<0.04 \mu \mathrm{M}$ for $\mathrm{PO}_{4},<0.21 \mu \mathrm{M}$ for $\mathrm{NO}_{3},<1 \mu \mathrm{M}$ for $\mathrm{Si}$ and $<0.20 \mu \mathrm{M}$ for $\mathrm{NH}_{4}$ for Stns 2, 3,5 , and 10. At Stn 6, the concentration of $\mathrm{PO}_{4}$ and $\mathrm{NO}_{3}$ in the surface water were higher $(0.13$ and $2.3 \mu \mathrm{M}$, respectively), while $\mathrm{Si}$ and $\mathrm{NH}_{4}$ levels were similar to those of the other stations. Below these depths, all nutrient levels increased (max. $0.71 \mu \mathrm{M}$ for $\mathrm{PO}_{4}, 9.9$ $\mu \mathrm{M}$ for $\mathrm{NO}_{3}$, and approx. $4.5 \mu \mathrm{M}$ for $\mathrm{Si}$ and $\mathrm{NH}_{4}$ ). The increase in $\mathrm{PO}_{4}$ and $\mathrm{NO}_{3}(0.20$ and $0.49 \mu \mathrm{M}$, respectively) was, however, less pronounced at Stn 2.

\section{Phytoplankton distribution}

All stations had a deep chl a maximum (DCM) range

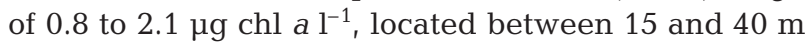
(Fig. 4). The total phytoplankton cell abundance exhibited a maximum typically located 0 to $15 \mathrm{~m}$ above the DCM (Fig. 4). The depth-integrated phytoplankton cell abundance over the upper 45 to $65 \mathrm{~m}$ ranged from a minimum of $0.7 \times 10^{8}(\operatorname{Stn} 2)$ to a maximum $2.7 \times 10^{8}$ cells $\mathrm{cm}^{-2}$ (Stn 3 ), of which $98 \pm 2 \%$ were picophytoplankton cells, regardless of the station. The phytoplankton communities at Stns 2, 3, 5, and 10 were numerically dominated by the cyanobacterium Synechococcus, accounting for $82 \pm 5 \%$ of the overall depth-integrated phytoplankton abundance. The concurrent picoeukaryotic groups comprised 4 to $10 \%$ and the nanoeukaryotes contributed $<1 \%$ of the depth integrated total abundance. The nutrient enriched Stn 6 presented a different phytoplankton community structure with a lower proportion of Synechococcus (23\% of the depth integrated cell abundance). The Pico I, II, and III accounted for 21,35 , and $12 \%$, respectively, and the nanoeukaryotes comprised $10 \%$ of the total community.

The cell abundance of Synechococcus sp. and Pico I was distributed similarly at Stns 2, 3, 5, and 10 (Fig. 4). Both groups developed a subsurface peak (15 to $35 \mathrm{~m}$ ) averaging $7 \pm 2 \times 10^{4}$ cells $\mathrm{ml}^{-1}$ for Synechococcus and $10 \pm 5 \times 10^{3} \mathrm{ml}^{-1}$ for Pico I. By comparison, Pico II and III abundance generally peaked at similar depth as Synechococcus and Pico I but in lesser abundance $(2 \pm$ $1 \times 10^{3} \mathrm{ml}^{-1}$ for each group). At Stn 6, all picophytoplankton groups showed similar distributions with high abundance in the upper $15 \mathrm{~m}\left(\sim 1 \times 10^{4}{\text { cells } \mathrm{ml}^{-1}}^{-1}\right.$ for Synechococcus, Pico I and II, and $3 \times 10^{3}$ cells ml $^{-1}$ for Pico III), decreasing gradually with depth.

The fraction of dead algal cells differed among picophytoplankton groups and stations (Fig. 4). Dead algal cells at $5 \mathrm{~m}$ ranged between 3 and $38 \%$, with the lowest values generally found for phytoplankton group Pico I (Fig. 4, Table 2). The depth profiles of dead cells were rather constant, except for Stn 10. At this coastal station, the fraction of dead Synechococcus and picoeukaryotes significantly increased (up to $75 \%$ ) below $15 \mathrm{~m}$.

In term of carbon biomass, the picophytoplankton groups comprised between 0.26 and $0.62 \mathrm{~g} \mathrm{C} \mathrm{m}^{-2}$, which corresponded to $48 \pm 18 \%$ of depth integrated phytoplankton carbon biomass. Through the entire study area, the carbon biomass of the picoeukaryotes equaled $(55 \pm 20 \%)$ that of the cyanobacterium Synechococcus.

\section{Virus community}

The virus community was divided into 4 groups according to nucleic acid green fluorescence and side scatter signature (Fig. 2B,C). Total viral abundance was between 3 and $7 \times 10^{7} \mathrm{ml}^{-1}$ in the top 15 to $30 \mathrm{~m}$, below which it progressively declined (to between 0.5 and $3 \times 10^{7} \mathrm{ml}^{-1}$, Fig. 5). The viral group V1 (characterized by the lowest nucleic acid green fluorescence, Fig. 2) had a similar distribution and largely dominated the virus community, making up $76 \pm 7 \%$ of the total abundance. The viral group V3 showed increased surface abundance at Stn $5\left(3 \times 10^{6} \mathrm{ml}^{-1}\right)$, where it comprised $11 \%$ of the total virus abundance (compared to 2 to $4 \%$ elsewhere). The abundance of the virus group V4 in the surface water of Stn 6 was at least 4 -fold higher $\left(8 \times 10^{5} \mathrm{ml}^{-1}\right)$ than at the other stations (Fig. 5). 


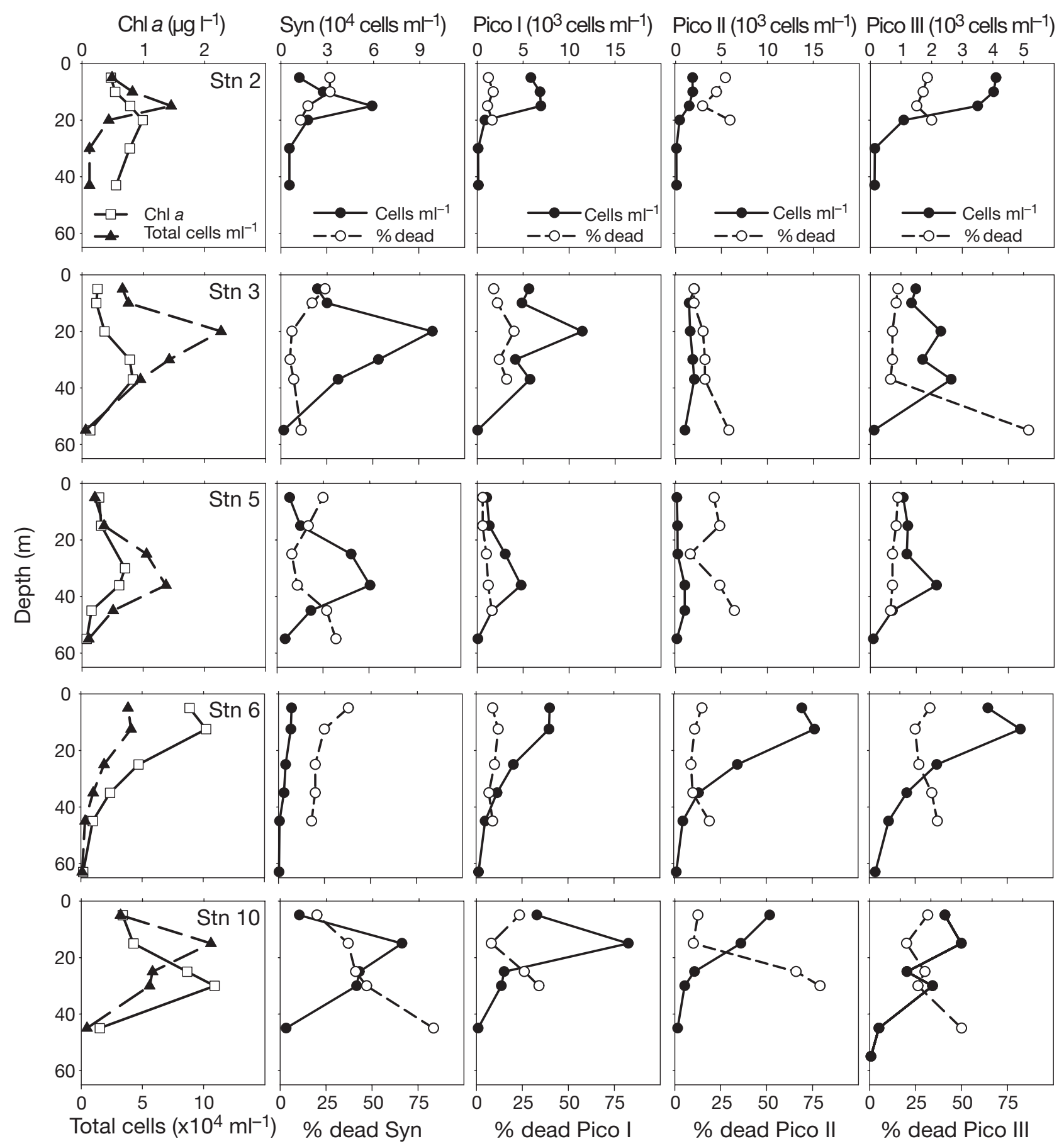

Fig. 4. Vertical distribution of $\mathrm{chl} \mathrm{a}\left(\mu \mathrm{g} \mathrm{l}^{-1}\right)$ and total picophytoplankton abundance $\left(\mathrm{ml}^{-1}\right)$ for the 5 stations investigated as well as abundance of the 4 picophytoplankton groups $(-)$ and their respective percentage of dead cells $(\%, O)$. Dead cells were discriminated based on their membrane integrity using the nucleic acid stain SYTOX Green

The viral diversity, as determined by PFGE, showed 5 to 17 distinct genome sizes per sample ranging from 30 to $280 \mathrm{~kb}$ (Fig. 6). All samples displayed viral genome sizes ranging between 30 and $145 \mathrm{~kb}$. Note that viral diversity at Stn 6 is likely to be under- estimated as only $20 \%$ of the plugged viruses migrated (reason unknown). The viral community was dominated by small sized viral genomes $(<100 \mathrm{~kb})$ comprising on average $98 \pm 1 \%$. The largest viral genomes $(105,115,145,155,165$, and $180 \mathrm{~kb})$ accounted for 0.4 
Table 2. Dilution-based specific growth $(\mu)$, microzooplankton grazing $\left(\mathrm{M}_{\mathrm{g}}\right)$, and viral lysis rates $\left(\mathrm{M}_{\mathrm{v}}\right)$ for the picophytoplankton groups and their abundance and fraction of dead cells at the onset of the experiment. Daily picophytoplankton carbon production $(\mathrm{CP})$ and the fraction of $\mathrm{CP}$ consumed by microzooplankton $\left(\mathrm{CP}_{\mathrm{g}}\right)$ and viruses $\left(\mathrm{CP}_{\mathrm{v}}\right)$ was calculated for each experiment.

${ }^{*}$ Growth and mortality rates significantly different from zero $(p \leq 0.05)$

\begin{tabular}{|c|c|c|c|c|c|c|c|c|}
\hline & $\begin{array}{l}\text { Abundance } \\
\left(10^{3} \text { ind. } \mathrm{ml}^{-1}\right)\end{array}$ & $\begin{array}{c}\mu \\
\left(\mathrm{d}^{-1}\right)\end{array}$ & $\begin{array}{c}\mathrm{M}_{\mathrm{g}} \\
\left(\mathrm{d}^{-1}\right)\end{array}$ & $\begin{array}{l}\mathrm{M}_{\mathrm{v}} \\
\left(\mathrm{d}^{-1}\right)\end{array}$ & $\begin{array}{c}\text { Dead } \\
(\%)\end{array}$ & 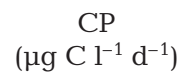 & $\mathrm{CP}_{\mathrm{g}}$ & $\mathrm{CP}_{\mathrm{v}}$ \\
\hline \multicolumn{9}{|l|}{$\operatorname{Stn} 2(5 \mathrm{~m})$} \\
\hline Synechococcus & 12 & $1.20^{*}$ & $0.12^{*}$ & 0.00 & 23 & 5.5 & 0.10 & 0.00 \\
\hline Picoeukaryote I & 2.7 & 0.05 & 0.07 & -0.01 & 6 & 0.0 & - & - \\
\hline Picoeukaryote II & 0.4 & $0.55^{*}$ & 0.10 & 0.06 & 27 & 0.2 & 0.19 & 0.11 \\
\hline Picoeukaryote III & 1.0 & $0.71^{*}$ & $0.28^{*}$ & -0.08 & 31 & 2.9 & 0.40 & 0.00 \\
\hline \multicolumn{9}{|l|}{ Stn $3(5 \mathrm{~m})$} \\
\hline Synechococcus & 24 & $0.86^{*}$ & 0.01 & 0.01 & 24 & 6.9 & 0.01 & 0.01 \\
\hline Picoeukaryote I & 5.6 & $0.12^{*}$ & $0.15^{*}$ & 0.03 & 9 & 0.1 & 1.25 & 0.25 \\
\hline Picoeukaryote II & 2.1 & $0.24^{*}$ & $0.14^{*}$ & -0.02 & 10 & 0.2 & 0.58 & 0.00 \\
\hline Picoeukaryote III & 1.5 & $0.06^{*}$ & $0.43^{*}$ & -0.05 & 15 & 0.0 & 2.87 & 0.00 \\
\hline \multicolumn{9}{|l|}{ Stn $3(37 \mathrm{~m})$} \\
\hline Synechococcus & 18 & $-0.08^{*}$ & 0.03 & 0.01 & 38 & 0.0 & - & - \\
\hline Picoeukaryote I & 9.2 & $0.17^{*}$ & 0.03 & 0.05 & 18 & 0.4 & 0.16 & 0.29 \\
\hline Picoeukaryote II & 1.2 & $0.18^{*}$ & 0.10 & 0.04 & 25 & 0.1 & 0.54 & 0.33 \\
\hline Picoeukaryote III & 0.7 & $0.45^{*}$ & 0.06 & $0.20^{*}$ & 20 & 0.8 & 0.13 & 0.44 \\
\hline \multicolumn{9}{|l|}{ Stn 5 (5 m) } \\
\hline Synechococcus & 8.0 & $0.81^{*}$ & 0.01 & 0.00 & 25 & 2.1 & 0.01 & 0.00 \\
\hline Picoeukaryote I & 1.0 & $0.41^{*}$ & $0.44^{*}$ & 0.01 & 3 & 0.1 & 1.08 & 0.02 \\
\hline Picoeukaryote II & 1.4 & $0.51^{*}$ & $0.31^{*}$ & 0.01 & 21 & 0.5 & 0.63 & 0.02 \\
\hline Picoeukaryote III & 1.1 & $0.49^{*}$ & $0.40^{*}$ & -0.04 & 5 & 2.0 & 0.81 & 0.00 \\
\hline \multicolumn{9}{|l|}{ Stn 6 (5 m) } \\
\hline Synechococcus & 8.5 & $0.17^{*}$ & 0.07 & -0.07 & 38 & 0.3 & 0.34 & 0.00 \\
\hline Picoeukaryote I & 8.0 & $0.37^{*}$ & $0.11^{*}$ & 0.00 & 9 & 0.7 & 0.28 & 0.00 \\
\hline Picoeukaryote II & 14 & $0.23^{*}$ & $0.15^{*}$ & -0.04 & 15 & 1.2 & 0.64 & 0.00 \\
\hline Picoeukaryote III & 3.9 & $0.34^{*}$ & $0.41^{*}$ & 0.00 & 33 & 2.9 & 1.20 & 0.00 \\
\hline \multicolumn{9}{|l|}{ Stn $10(5 \mathrm{~m})$} \\
\hline Synechococcus & 12 & $2.10^{*}$ & $0.72^{*}$ & -0.02 & 20 & 12.0 & 0.34 & 0.00 \\
\hline Picoeukaryote I & 6.6 & $0.35^{*}$ & 0.01 & $0.16^{*}$ & 13 & 0.6 & 0.00 & 0.43 \\
\hline Picoeukaryote II & 10 & $0.31^{*}$ & $0.29^{*}$ & 0.02 & 23 & 1.5 & 0.93 & 0.06 \\
\hline Picoeukaryote III & 2.5 & $0.34^{*}$ & $0.13^{*}$ & $0.23^{*}$ & 32 & 3.0 & 0.38 & 0.67 \\
\hline
\end{tabular}

to $5.5 \%$ of the viral community, with the greatest contribution found at Stn 5. The viral diversity examined at the DCM (Stns 2 and 3) showed an increased richness and abundance of viral genomes ranging from 85 to $280 \mathrm{~kb}$ as compared to the surface sample.

\section{Viral lysis and microzooplankton grazing}

Algal growth rates in the surface waters varied considerably among the picophytoplankton groups (from 0.1 to $2.1 \mathrm{~d}^{-1}$, Table 2), without a clear geographical trend. The growth rates of the picoeukaryotes varied on average between 0.25 and $0.41 \mathrm{~d}^{-1}(0.25 \pm 0.15,0.34 \pm 0.16$ and $0.41 \pm 0.20 \mathrm{~d}^{-1}$ for Pico I, II, and III, respectively). The picocyanobacterium Synechococcus consistently presented the highest growth rates $\left(0.81\right.$ to $\left.2.1 \mathrm{~d}^{-1}\right)$, except for Stn $6\left(0.17 \mathrm{~d}^{-1}\right)$ and Stn 3 at the DCM $\left(-0.08 \mathrm{~d}^{-1}\right)$. Despite the relative high growth rates, Synechococcus loss rates showed considerable variation with typically low grazing and viral lysis rates (Table 2, Fig. 7). A high grazing rate on Synechococcus was only detected at Stn 10 $\left(0.72 \mathrm{~d}^{-1}\right.$ vs. $0.05 \pm 0.05 \mathrm{~d}^{-1}$ at the offshore Stns $2,3,5$, and $6)$. The independent FLC methodology yielded similar Synechococcus grazing rates (0.03 to $\left.0.61 \mathrm{~d}^{-1}\right)$. Results from both approaches did not significantly differ ( $t$-test, $\mathrm{p}>0.05$ ) and were highly correlated (Spearman rank order correlation, $\left.\mathrm{r}_{\mathrm{S}}=0.98, \mathrm{n}=5, \mathrm{p}<0.05\right)$. In contrast to Synechococcus, the picoeukaryotic groups were substantially grazed upon at all stations (average $0.13 \pm$ $0.16 \mathrm{~d}^{-1}$ for Pico I, $0.18 \pm 0.10 \mathrm{~d}^{-1}$ for Pico II, and $0.29 \pm$ $0.16 \mathrm{~d}^{-1}$ for Pico III). Furthermore, viral lysis in the surface water of Stn 10 and at the DCM of Stn 3 was substantial ( 0.16 to $0.23 \mathrm{~d}^{-1}$ ) and significant ( $t$-test, $\left.\mathrm{p}<0.05\right)$ for the picoeukaryotic groups Pico I and Pico III (Fig. 7 \& Table 2). In the surface waters of the offshore Stns 2, 3, 5, and 6 , viral lysis could be detected but estimates were not statistically significant $(t$-test, $p>0.05)$. For those sta- 


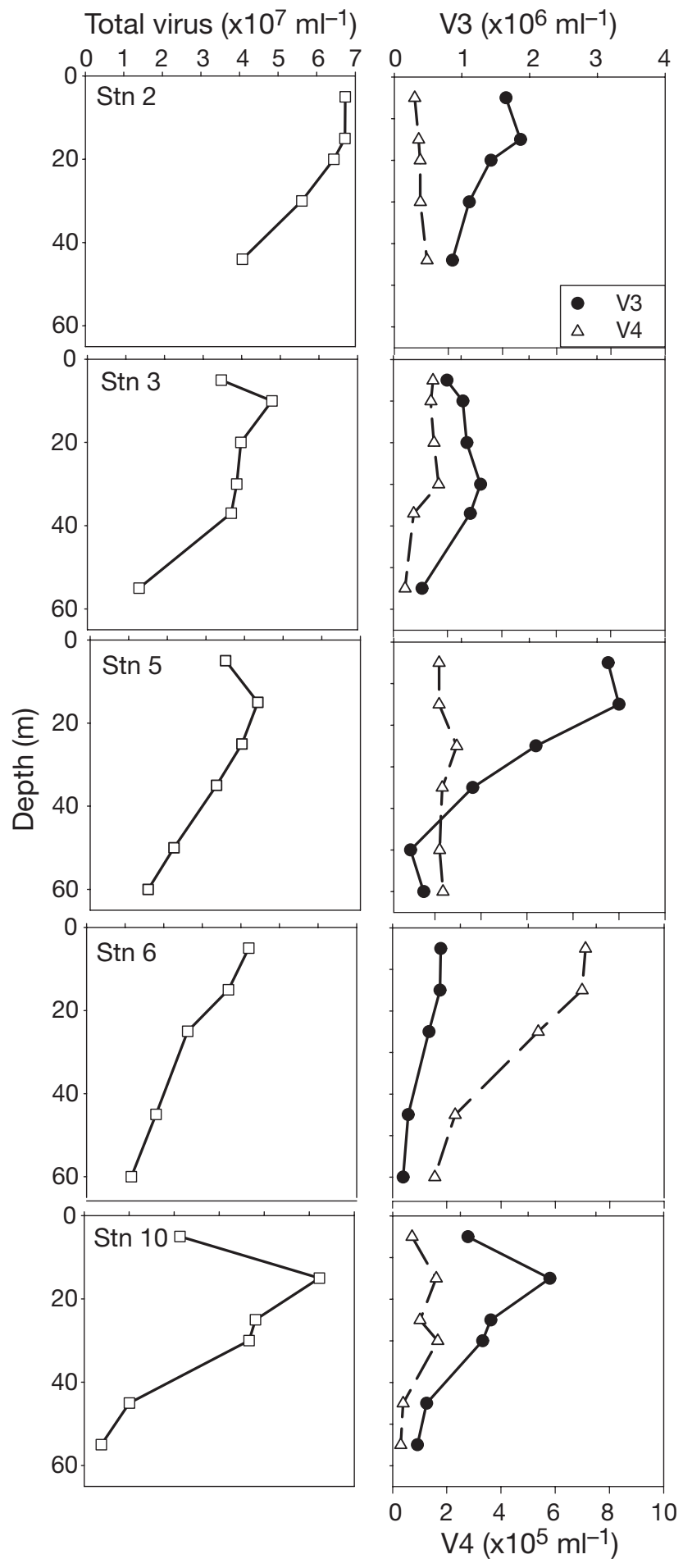

Fig. 5. Vertical distribution of total virus abundance, viral group V4 and group V3 (virus $\mathrm{ml}^{-1}$ )

tions, power analysis revealed that the $t$-tests had significant power (0.8) to detect average viral lysis rates of 0.1 $\mathrm{d}^{-1}$ (range: 0.04 to $0.2 \%$ ). Viral lysis rates below this value might not be significantly captured.

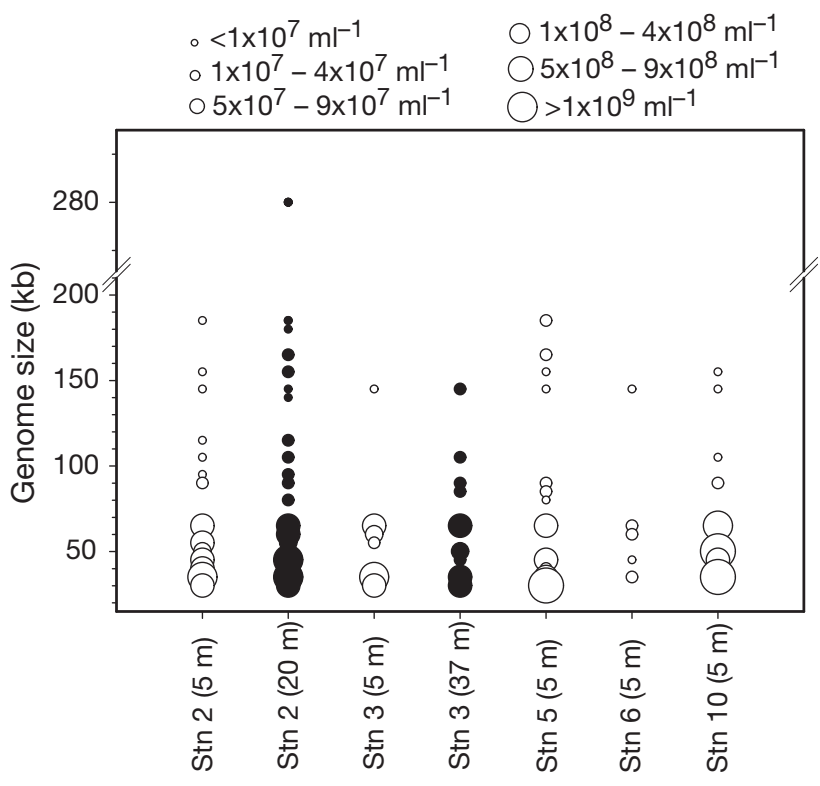

Fig. 6. Relative abundance (indicated by the area of the circles) of viral genome sizes, based on the results of 2 PFGE runs using different settings to determine small sized (30 to $100 \mathrm{~kb}$ ) and large sized genomes (50 to $400 \mathrm{~kb}$ ). White and black circles represent stations sampled at surface and DCM depths, respectively

\section{Carbon production and losses}

The total picophytoplankton carbon production (CP) varied greatly between stations (0.5 to $15 \mu \mathrm{g} \mathrm{C}^{-1} \mathrm{~d}^{-1}$, Table 2) with the highest value found at the coastal Stn $10\left(15 \mu \mathrm{g} \mathrm{C}^{-1} \mathrm{~d}^{-1}\right)$. Overall, the picoeukaryotic groups contributed substantially to the total picophytoplankton CP (on average $57 \pm 35 \%$ ).

The total picophytoplanktonic carbon losses due to viral lysis and microzooplankton grazing $(0.3$ to

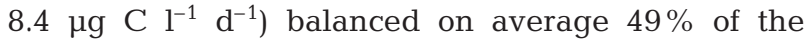
picophytoplanktonic $\mathrm{CP}$, with considerable variation among picophytoplankton groups. Looking specifically at the picoeukaryotes, most of the CP was actually counterbalanced by microzooplankton grazing and viral lysis (on average per group 60 to $120 \%$ ). For Synechococcus, however, only $10 \%$ of the CP was lost.

Carbon losses were due to both viral lysis and microzooplankton grazing in the surface waters of Stn 10 (contributing 29 and $71 \%$, respectively), in contrast to the other stations where microzooplankton grazing alone accounted for the total carbon loss in the surface waters (94 to $100 \%$ ). At the DCM of Stn 3, however, virally mediated carbon loss $\left(0.2 \mu \mathrm{g} \mathrm{C}^{-1} \mathrm{~d}^{-1}\right)$ prevailed over grazing-induced carbon loss $\left(0.1 \mu \mathrm{g} \mathrm{C}^{-1} \mathrm{~d}^{-1}\right)$ and comprised $32 \%$ of the picophytoplankton $\mathrm{CP}(0.5 \mu \mathrm{g} \mathrm{C}$ $\left.\mathrm{l}^{-1} \mathrm{~d}^{-1}\right)$. 


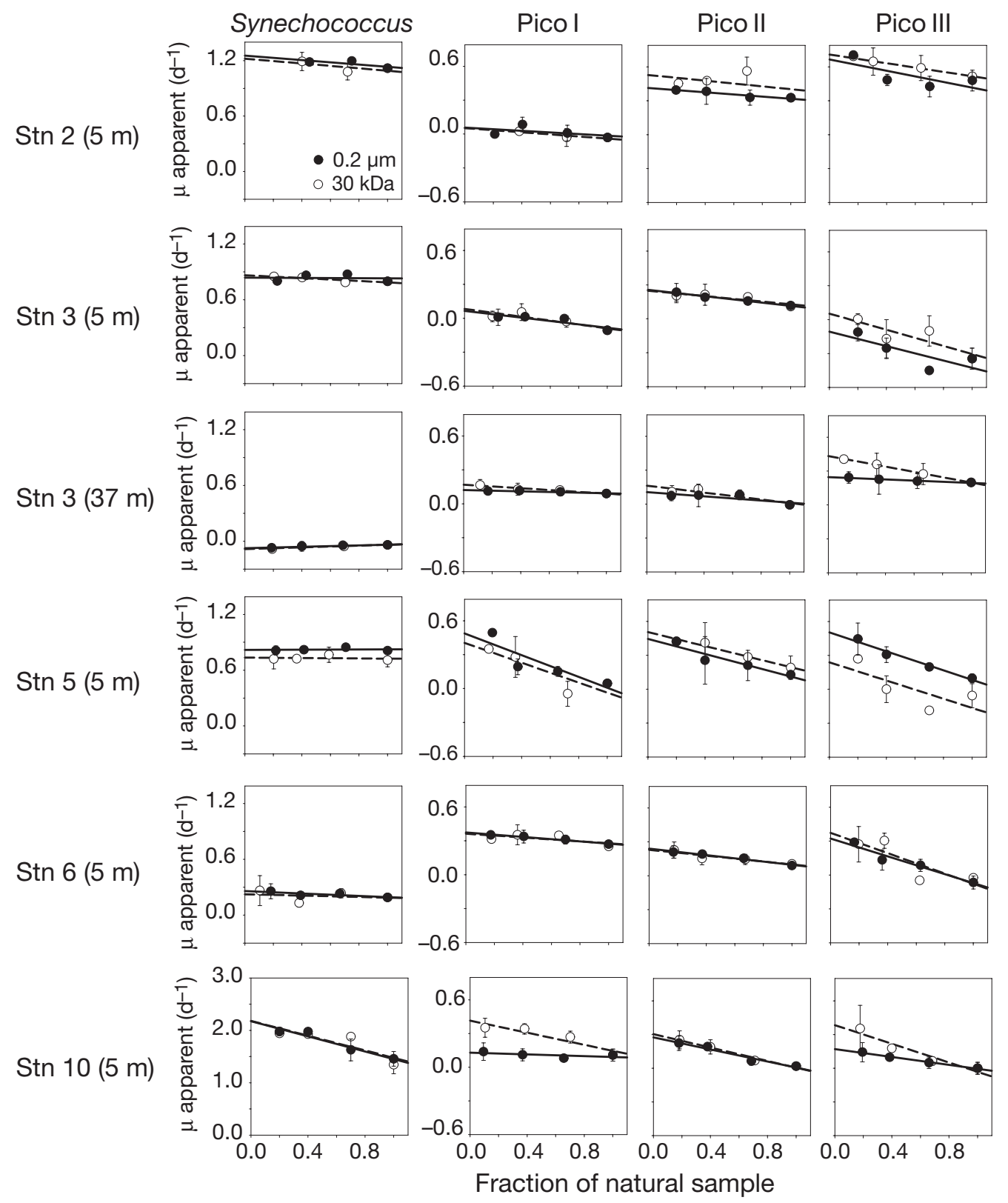

Fig. 7. Apparent growth rate vs. fraction of natural water in the parallel dilution experiment for different picophytoplankton groups. Experiments were performed in $30 \mathrm{kDa}$ ultrafiltrate (no grazer, no virus) and $0.2 \mu \mathrm{m}$ (no grazer) filtered seawater. Microzooplankton grazing rates correspond to the regression slope obtained with the $0.2 \mu \mathrm{m}$ dilution series. Viral lysis rates correspond to the difference of regression coefficients of the $0.2 \mu \mathrm{m}$ and $30 \mathrm{kDa}$ series. Error bars: $\mathrm{SD}(\mathrm{n}=3)$

\section{DISCUSSION}

\section{Microzooplankton grazing and viral lysis}

This study explored geographical variation in phytoplankton losses due to microzooplankton grazing and viral lysis across the North Sea during summer 2003. Based on T-S diagrams obtained during the MOMAP-2 expedition, 4 hydrographic regions were distinguished in the North Sea (C. P. D. Brussaard unpubl. data). The 5 stations we studied are representative of these 4 regions. As expected during summer, all 5 stations exhibited low surface nutrient concentrations. The phytoplankton community naturally distributed into 6 clusters with ESD ranging from 1 to $20 \mu \mathrm{m}$, largely dominated by picophytoplankton $(<3 \mu \mathrm{m})$. The extent of losses due to viral lysis and microzooplankton varied widely among the picophytoplankton groups and geographical locations. 
Microzooplankton were the main mortality agents (on average $0.19 \pm 0.18 \mathrm{~d}^{-1}$ ), but their impact differed among the picophytoplankton groups. Synechococcus was under the lowest grazing pressure $\left(0.04 \pm 0.05 \mathrm{~d}^{-1}\right)$ except at the coastal Stn $10\left(0.72 \mathrm{~d}^{-1}\right)$. The strong correlation between the 2 independent grazing assays used during this study (dilution technique and FLC method) indicates that the low rates did not arise from experimental artefacts, but rather were due to preferential grazing. Previous work in the same region found that 1 to $2 \mu \mathrm{m}$ sized phytoplankton experienced lower grazing rates $\left(0.07 \mathrm{~d}^{-1}\right)$ than the 2 to $3 \mu \mathrm{m}$ size class $\left(0.20 \mathrm{~d}^{-1}\right.$; Kuipers \& Witte 1999). Another study conducted in oligotrophic surface waters also reported consistently higher predation rates on picoeukaryotes (up to 3-fold) than Synechococcus (Worden et al. 2004). The differential grazing observed in offshore vs. coastal stations could be due to distinct predator communities that preferentially consumed certain picophytoplankton populations. For instance, Synechococcus is selectively egested or digested by some heterotrophic nanoflagellates (Boenigk et al. 2001, Guillou et al. 2001) and ciliates (Christaki et al. 1999).

Significant viral lysis rates (up to $0.23 \mathrm{~d}^{-1}$ ) were recorded along the Norwegian coast for picoeukaryotic groups Pico I and Pico III (Stn 10), and at the DCM of the offshore Stn 3 for Pico III. These results indicate that about $20 \%$ of the abundance of each group underwent viral lysis on a daily basis. Pigment analysis revealed that prasinophytes comprised 20 to $30 \%$ of the total phytoplankton chl $a$ at the 2 stations (compared to 0.1 to $5 \%$ at the other stations; C. P. D. Brussaard unpubl. data). Interestingly, viruses infecting the prasinophyte Micromonas pusilla were also present in high titer $\left(1 \times 10^{3} \mathrm{ml}^{-1}\right)$ at Stns 2 and 10 (compared to titers of $\leq 1 \times 10^{2} \mathrm{ml}^{-1}$ at other stations; C. P. D. Brussaard unpubl. data). Our observations suggest that viruses may be responsible for mortality in the $M$. pusilla population. Additionally, Evans et al. (2003) reported substantial virally induced turnover rates of M. pusilla (between 9 and $25 \% \mathrm{~d}^{-1}$ ) for the Norwegian coast during late spring.

The variable lysis rates for the different phytoplankton groups at the different stations tested indicate a differential viral control among picophytoplanktonic groups and their area of occurrence. Comparisons with the literature are restricted, because most studies on viral lysis in oligotrophic environments have focused on Synechococcus (Waterbury \& Valois 1993, Suttle \& Chan 1994, Garza \& Suttle 1998, Baudoux et al. 2007). However, these previous studies, using different approaches, consistently reported low viral rates for Synechococcus. Our findings support this relatively small impact of viruses on Synechococcus mortality in surface oligotrophic waters, despite its numerical dominance.
Previous studies suggested that dilution in virus-free water reduced the growth rates of picophytoplankton, including Synechococcus and picoeukaryotes (Suttle et al. 1996, Kimmance et al. 2007). In contrast, we observed similar or higher phytoplankton growth rates in the $30 \mathrm{kDa}$ (grazer and virus-free) than in the $0.2 \mu \mathrm{m}$ (grazer-free) series, regardless of the phytoplankton group considered. Similar findings have been recorded in the oligotrophic subtropical northeastern Atlantic Ocean (Baudoux et al. 2007). Our approach (using a different experimental set-up than in the studies conducted by Suttle et al. 1996 and Kimmance et al. 2007) thus shows that the dilution method can be used in oligotrophic environments. Testing the sensitivity of our experimental approach showed, however, that viral lysis rates $<0.1 \mathrm{~d}^{-1}$ were not effectively estimated, as also reported by Kimmance et al. (2007). Increasing the sensitivity of the dilution assay could be achieved, for example, by increasing the number of replicates, or by improving the accuracy of the counting procedure (i.e. a longer counting time for the more diluted samples, provided the in situ temperature can be maintained). Although such improvements may be difficult to implement, they are worth considering as the modified dilution assay does provide direct estimates of 2 major loss factors (grazing and viral lysis) simultaneously, as well as providing information on their relative impact on concurrent phytoplankton groups.

Although little is known about the composition of the marine virus community, algal viruses most often exhibit larger genome size and higher nucleic acid green fluorescence upon FCM analysis than bacteriophages (Larsen et al. 2001, Brussaard 2004a, Duhamel et al. 2006). Consequently, the viral group V4 and the viruses with genome size $>100 \mathrm{~kb}$ were operationally defined as putative algal viruses, and the viral group V3 may also include algal viruses (Brussaard et al. 2000, Larsen et al. 2001). Occasionally, high standing stocks of the viral groups V4 $\left(8 \times 10^{5} \mathrm{ml}^{-1}\right.$, Stn 6$)$ and V3 $\left(4 \times 10^{6} \mathrm{ml}^{-1}, \mathrm{Stn} 5\right)$ were recorded. There are several explanations that could account for the lack of viral lysis even in the presence of algal viruses. (1) The modified technique exclusively captures the viral lysis of newly infected algal hosts within the incubation period $(24 \mathrm{~h})$, whereas the standing stock of algal viruses is the result from production before the incubation period. (2) Most algal viruses described to date have stringent host ranges. Thereby, it may be that a high genetic diversity of the algal host species of interest (e.g. Synechococcus, Scanlan \& West 2002) reduces the chance of encounter with a suitable virus. (3) The ability of Synechococcus to resist co-occurring viruses (Waterbury \& Valois 1993, Stoddard et al. 2007) could also lead to a stable coexistence between the host and their virus, also explaining the absence of viral lysis. 
(4) The viruses present in the sample may not have been specific to the co-occurring Synechococcus or picoeukaryote populations. Relatively high abundance of the prymnesiophytes Chrysochromulina ericina and Emiliania huxleyi have been reported in waters adjacent to Stn 6 (Riegman \& Kraay 2001 and references therein). Both of these nanoeukaryotes can be subject to viral lysis during summer blooms in the North Sea (Brussaard et al. 1996b). Although no phytoplankton species inventory was performed during our expedition, pigment analysis revealed that prymnesiophytes, potentially $C$. ericina and E. huxleyi, comprised most of the Chl $a$ at Stn 6 (C.P.D. Brussaard unpubl. data). Furthermore, the FCM signature of the V4 viral group resembled that of $C$. ericina virus (Brussaard 2004b) or E. huxleyi virus (Jacquet et al. 2002). (5) The absence of viral lysis could be caused by a reduced viral infectivity. In the surface layer of the ocean environmental factors such as high solar radiation, and particularly UV radiation (UVR), can severely alter the infectivity of algal viruses (Cottrell \& Suttle 1995, Garza \& Suttle 1998, Jacquet \& Bratbak 2003). It is noteworthy that viral lysis was detected exclusively in light attenuated environments in the present study. The Norwegian coastal Stn 10 had the shallowest euphotic zone $(23 \mathrm{~m}$, irradiance approximately half of that at other stations), whereas light intensity at the DCM at Stn 3 was very low (3 $\mu \mathrm{mol}$ quanta $\mathrm{m}^{-2} \mathrm{~s}^{-1}$ ). Viral lysis rates of picoeukaryotes at the DCM were not only enhanced compared to the surface, but the richness and abundance of putative algal viruses (>100 kb) was also higher. Such a shift in viral community structure was confirmed for other stations where viral diversity was also studied at the DCM (Stn 2; C. P. D. Brussaard unpubl. data). Additional research is, of course, required to test whether algal virus diversity and lysis rates are consistently higher in the DCM relative to surface water, and whether the ambient light level and composition may be responsible for the differential impact of viruses on picophytoplankton mortality.

The finding of occasional low virally mediated algal cell lysis rates in combination with a relatively high fraction of dead algal cells (determined using SYTOX Green assay) indicates that viral lysis rates and standing stock of dead cells are not necessarily comparable. Although viral lysis may cause cell membrane permeabilization for the picophytoplankton under viral control (namely Pico I at Stn 10 and Pico III at Stns 3 and 10), other factors causing cell lysis may also be involved at stations where low rates of viral lysis were detected (Franklin et al. 2006). Among these factors, water temperature may have altered Synechococcus viability, as reported by Alonso-Laita \& Agusti (2006). Temperature was significantly and negatively correlated with Synechococcus dead cells and growth rate.
The relatively low temperature at the DCM of Stn 3 $\left(9.9^{\circ} \mathrm{C}\right.$ as compared to 12.8 to $19.2^{\circ} \mathrm{C}$ in the surface waters) may have enhanced the number of dead Synechococcus, yet negative effects of light limitation on Synechococcus growth (Moore et al. 1995) and membrane integrity (Alonso-Laita \& Agusti 2006) cannot be excluded.

\section{Implications for the carbon cycle}

The distinction and quantification of phytoplankton losses due to lysis and microzooplankton grazing is essential for an optimal understanding of the carbon pathway in marine environments. Our results showed that locally, viral lysis yielded substantial carbon release, amounting to 0.2 and $2.4 \mu \mathrm{g} \mathrm{C} \mathrm{l}^{-1} \mathrm{~d}^{-1}$ at the DCM of Stn 3 and in the surface layer of Stn 10, respectively. The measure obtained at the DCM compared well with an earlier study in the DCM waters of the subtropical northeastern Atlantic Ocean (0.1 to $0.3 \mu \mathrm{g}$ $\mathrm{C}^{-1} \mathrm{~d}^{-1}$; Baudoux et al. 2007). In contrast, the amount of virally induced carbon release in the Norwegian coastal waters $\left(2.4 \mu \mathrm{g} \mathrm{C} \mathrm{l}^{-1} \mathrm{~d}^{-1}\right)$ largely exceeds those reported in the surface coastal waters of the Gulf of Mexico (0.12 to $0.35 \mu \mathrm{g} \mathrm{C} \mathrm{l}^{-1} \mathrm{~d}^{-1}$; Wilhelm \& Suttle 1999 and references therein). The lower values found by Wilhelm \& Suttle (1999) may be due to the limited number of potential hosts they included in their study (only Micromonas pusilla and Synechococcus); therefore, the impact of algal viruses on carbon flow may be higher than previously assumed.

In addition to virally induced carbon release, the leakage of soluble compounds from cells with compromised membrane may constitute another relevant source of DOM. However, the classification of cells as dead cannot be directly converted to cell lysis rates, as the elapsed time between the physiological death and subsequent lysis is unknown. Therefore, the magnitude and quantification of this process needs further investigation.

The carbon losses generated by microzooplankton grazing were generally higher (range: 0.1 to $6.0 \mu \mathrm{g} \mathrm{C}$ $\mathrm{l}^{-1} \mathrm{~d}^{-1}$ ) than those caused by viral lysis (range: 0.2 to

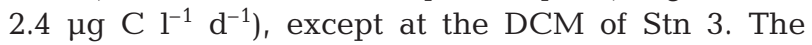
picoeukaryotes constituted the primary source of carbon for the microzooplankton, with on average $77 \%$ (range: 55 to $140 \%$ ) of the picoeukaryotic carbon production lost by microzooplankton grazing (as compared to $10 \%$ for Synechococcus). Our results substantiate earlier studies suggesting an important role of picoeukaryotes for carbon transfer to higher levels of the food web in oligotrophic waters (Worden et al. 2004). Overall, microzooplankton consumed $40 \pm 27 \%$ $\mathrm{d}^{-1}$ of the total picophytoplankton carbon production 
$(C P)$, which is slightly lower than the general estimate of consumption by microzooplankton of $59 \% \mathrm{~d}^{-1}$ reported for temperate ecosystems (Calbet \& Landry 2004). The analysis by Calbet \& Landry (2004) includes, however, all seasons and different geographic locations. The variability and algal group specificity of grazing and virally induced mortality rates will affect the structure of the plankton community and carbon cycling differently and should, therefore, be addressed in more detail in future analyses of phytoplankton mortality and carbon cycling.

Acknowledgements. We thank the captain and crew of the RV 'Pelagia' for excellent shipboard support. We thank the nutrient service lab for technical support and C. Chenard, V. Parada, and D. Van de Waal for their assistance during the cruise. H. Witte is greatly acknowledged for valuable statistical advice and K. Rypien for editing this manuscript. We thank the anonymous reviewers for their constructive suggestions on this manuscript. This work was supported by the Research Council for Earth and Life Sciences (ALW) with financial aid from the Netherlands Organization for Scientific Research (NWO).

\section{LITERATURE CITED}

Agusti S, Satta MP, Mura MP, Benavent E (1998) Dissolved esterase activity as a tracer of phytoplankton lysis: evidence of high phytoplankton lysis rates in the northwestern Mediterranean. Limnol Oceanogr 43:1836-1849

Alonso-Laita P, Agusti S (2006) Contrasting patterns of phytoplankton viabilily in the subtropical NE Atlantic Ocean. Aquat Microb Ecol 43:67-78

Baudoux AC, Noordeloos AAM, Veldhuis MJW, Brussaard CPD (2006) Virally induced mortality of Phaeocystis globosa during two spring blooms in temperate coastal waters. Aquat Microb Ecol 44:207-217

Baudoux AC, Veldhuis MJW, Witte HJ, Brussaard CPD (2007) Viruses as mortality agents of picophytoplankton in the deep chlorophyll maximum layer during IRONAGES III. Limnol Oceanogr 52:2519-2529

Bayne BL, Clarke KR, Moore MN (1981) Some practical considerations in the measurement of pollution effects on bivalve molluscs, and some possible ecological consequences. Aquat Toxicol 1:159-174

Berges JA, Falkowski PG (1998) Physiological stress and cell death in marine phytoplankton: induction of proteases in response to nitrogen or light limitation. Limnol Oceanogr 43:129-135

Berman-Frank I, Bidle KD, Haramaty L, Falkowski PG (2004) The demise of the marine cyanobacterium, Trichodesmium spp., via an autocatalyzed cell death pathway. Limnol Oceanogr 49:997-1005

Bertilsson S, Berglund O, Karl DM, Chisholm SW (2003) Elemental composition of marine Prochlorococcus and Synechococcus: implications for the ecological stoichiometry of the sea. Limnol Oceanogr 48:1721-1731

> Boenigk J, Matz C, Jurgens K, Arndt H (2001) The influence of preculture conditions and food quality on the ingestions and digestion process of three species of heterotrophic nanoflagellates. Microb Ecol 42:168-176

Brussaard CPD (2004a) Viral control of phytoplankton populations - a review. J Eukaryot Microbiol 51:125-138
Brussaard CPD (2004b) Optimization of procedures for counting viruses by flow cytometry. Appl Environ Microbiol 70: 1506-1513

Brussaard CPD, Riegman R, Noordeloos AAM, Cadée GC and others (1995) Effects of grazing, sedimentation and phytoplankton cell lysis on the structure of a coastal pelagic food web. Mar Ecol Prog Ser 123:259-271

Brussaard CPD, Gast GJ, Van Duyl FC, Riegman R (1996a) Impact of phytoplankton bloom magnitude on a pelagic microbial food web. Mar Ecol Prog Ser 144:211-221

Brussaard CPD, Kempers RS, Kop AJ, Riegman R, Heldal M (1996b) Virus-like particles in a summer bloom of Emiliania huxleyi in the North Sea. Aquat Microb Ecol 10: 105-113

Brussaard CPD, Marie D, Bratbak G (2000) Flow cytometric detection of viruses. J Virol Methods 85:175-182

Brussaard CPD, Marie D, Thyrhaug R, Bratbak G (2001) Flow cytometric analysis of phytoplankton viability following viral infection. Aquat Microb Ecol 26:157-166

> Brussaard CPD, Kuipers B, Veldhuis MJW (2005a) A mesocosm study of Phaeocystis globosa population dynamics. 1. Regulatory role of viruses in bloom. Harmful Algae $4: 859-874$

Calbet A, Landry MR (2004) Phytoplankton growth, microzooplankton grazing, and carbon cycling in marine systems. Limnol Oceanogr 49:51-57

Christaki U, Jacquet S, Dolan JR, Vaulot D, Rassoulzadegan F (1999) Growth and grazing on Prochlorococcus and Synechococcus by two marine ciliates. Limnol Oceanogr 44: $52-61$

Cottrell MT, Suttle CA (1995) Dynamics of a lytic virus infecting the photosynthetic marine picoflagellate Micromonas pusilla. Limnol Oceanogr 40:730-739

Duhamel S, Domaizon-Pialat I, Personnic S, Jacquet S (2006) Assessing the microbial community dynamics and the role of bacteriophages in bacterial mortality in Lake Geneva. Rev Sci Eau 19:115-126

DuRand MD, Green RE, Sosik HM, Olson RJ (2002) Diel variations in optical properties of Micromonas pusilla (Prasinophyceae). J Phycol 38:1132-1142

$>$ Evans C, Archer SD, Jacquet S, Wilson WH (2003) Direct estimates of the contribution of viral lysis and microzooplankton grazing to the decline of a Micromonas spp. population. Aquat Microb Ecol 30:207-219

> Franklin DJ, Brussaard CPD, Berges JA (2006) What is the role and nature of programmed cell death in phytoplankton ecology? Eur J Phycol 41:1-14

> Garza DR, Suttle CA (1998) The effect of cyanophages on the mortality of Synechococcus spp. and selection for UV resistant viral communities. Microb Ecol 36:281-292

Geider RJ, Delucia EH, Falkowski PG, Finzi AC and others (2001) Primary productivity of planet Earth: biological determinants and physical constraints in terrestrial and aquatic habitats. Glob Change Biol 7:849-882

Guillou L, Jacquet S, Chretiennot-Dinet MJ, Vaulot D (2001) Grazing impact of two small heterotrophic flagellates on Prochlorococcus and Synechococcus. Aquat Microb Ecol 26:201-207

Jacquet S, Bratbak G (2003) Effects of ultraviolet radiation on marine virus-phytoplankton interactions. FEMS Microbiol Ecol 44:279-289

Jacquet S, Heldal M, Iglesias-Rodriguez D, Larsen A, Wilson W, Bratbak G (2002) Flow cytometric analysis of an Emiliania huxleyi bloom terminated by viral infection. Aquat Microb Ecol 27:111-124

Kimmance SA, Wilson WH, Archer SD (2007) Modified dilution technique to estimate viral virus grazing mortality of 
phytoplankton: limitations associated with method sensitivity in natural waters. Aquat Microb Ecol 49:207-222

Kuipers BR, Witte HJ (1999) Grazing impact of microzooplankton on different size classes of algae in the North Sea in early spring and mid-summer. Mar Ecol Prog Ser 180: 93-104

Landry MR, Hassett RP (1982) Estimating the grazing impact of marine microzooplankton. Mar Biol 67:283-288

Landry MR, Constantinou J, Latasa M, Brown SL, Bidigare RR, Ondrusek ME (2000) Biological response to iron fertilization in the eastern equatorial Pacific (IronEx II). Dynamics of phytoplankton growth and microzooplankton grazing. Mar Ecol Prog Ser 201:57-72

Larsen A, Castberg T, Sandaa RA, Brussaard CPD and others (2001) Population dynamics and diversity of phytoplankton, bacteria and viruses in a seawater enclosure. Mar Ecol Prog Ser 221:47-57

Moore LR, Goericke R, Chisholm SW (1995) Comparative physiology of Synechococcus and Prochlorococcus: influence of light and temperature on growth, pigments, fluorescence and absorptive properties. Mar Ecol Prog Ser 116:259-275

Raven JA (1998) The twelfth Tansley Lecture. Small is beautiful: the picophytoplankton. Funct Ecol 12:503-513

Riegman R, Kraay GW (2001) Phytoplankton community structure derived from HPLC analysis of pigments in the Faroe-Shetland Channel during summer 1999: the distribution of taxonomic groups in relation to physical/chemical conditions in the photic zone. J Plankton Res 23:191-205

Riegman R, Kuipers BR, Noordeloos AAM, Witte HJ (1993) Size-differential control of phytoplankton and the structure of plankton communities. Neth J Sea Res 31: 255-265

Scanlan DJ, West NJ (2002) Molecular ecology of the marine cyanobacterial genera Prochlorococcus and Synechococcus. FEMS Microbiol Ecol 40:1-12

Sherr EB, Sherr BF (1993) Protistian grazing rates via uptake of fluorescently labeled prey. In: Kemp PF, Sherr BF, Sherr EB, Cole JJ (eds) Microbial ecology. Lewis Publishers, Boca Raton, FL, p 695-701

Smetacek VS (1985) Role of sinking diatom life-history cycles: ecological, evolutionary and geological significance. Mar Biol 84:239-251

Steward GF (2001) Fingerprinting viral assemblages by pulsed field gel electrophoresis. In: Paul JH (ed) Methods

Editorial responsibility: Gunnar Bratbak, Bergen, Norway in marine microbiology, Vol 30. Academic Press, London, p 85-103

Stoddard LI, Martiny JBH, Marston MF (2007) Selection and characterization of cyanophage resistance in marine Synechococcus strains. Appl Environ Microbiol 73: 5516-5522

Suttle CA, Chan AM (1994) Dynamics and distribution of cyanophages and their effect on marine Synechococcus spp. Appl Environ Microbiol 60:3167-3174

Suttle CA, Chan AM, Cottrell MT (1990) Infection of phytoplankton by viruses and reduction of primary productivity. Nature 347:467-469

> Suttle CA, Chan AM, Cottrel MT (1991) Use of ultrafiltration to isolate viruses from seawater which are pathogens of marine plankton. Appl Environ Microbiol 57:721-726

Suttle CA, Chan AM, Rodda KM, Short SM, Weinbauer MG, Garza DR, Wilhelm SW (1996) The effect of cyanophages on Synechococcus spp. during a bloom in the western Gulf of Mexico. EOS J Immunol Immunofarmacol 76(Suppl): OS207-OS208

Veldhuis MJW, Kraay GW (2004) Phytoplankton in the subtropical Atlantic Ocean: towards a better assessment of biomass and composition. Deep-Sea Res I 51:507-530

Veldhuis MJW, Kraay GW, Timmermans KR (2001) Cell death in phytoplankton: correlation between changes in membrane permeability, photosynthetic activity, pigmentation and growth. Eur J Phycol 36:167-177

Verity PG, Robertson CY, Tronzo CR, Andrews MG, Nelson JR, Sieracki ME (1992) Relationships between cell volume and the carbon and nitrogen content of marine photosynthetic nanoplankton. Limnol Oceanogr 37:1434-1446

> Waterbury JB, Valois FW (1993) Resistance to co-occurring phages enables marine Synechococcus communities to coexist with cyanophages abundant in seawater. Appl Environ Microbiol 59:3393-3399

- Wilhelm SW, Suttle CA (1999) Viruses and nutrient cycles in the sea. Bioscience 49:781-788

Wommack KE, Ravel J, Hill RT, Chun J, Colwell RR (1999) Population dynamics of Chesapeake Bay virioplankton: total-community analysis by pulsed-field gel electrophoresis. Appl Environ Microbiol 65:231-240

Worden AZ, Nolan JK, Palenik B (2004) Assessing the dynamics and ecology of marine picophytoplankton: the importance of the eukaryotic component. Limnol Oceanogr 49:168-179

Submitted: November 8, 2007; Accepted: April 28, 2008 Proofs received from author(s): June 25, 2008 